
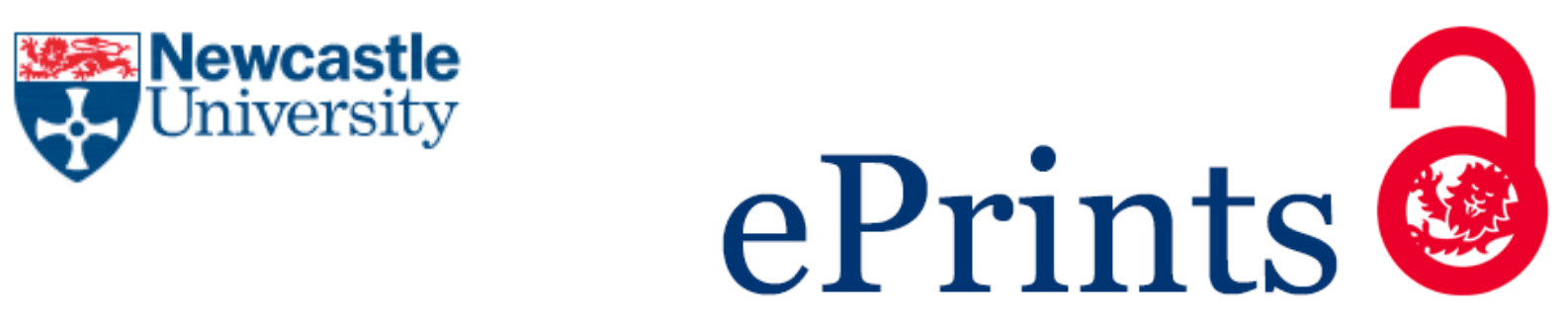

Blazek M, Windram-Geddes $M$.

Editorial: Thinking and doing children's emotional geographies.

Emotion, Space and Society 2013, 9, 1-3.

\title{
Copyright:
}

(C) 2013. This manuscript version is made available under the CC-BY-NC-ND 4.0 license

DOI link to article:

http://dx.doi.org/10.1016/i.emospa.2013.07.006

Date deposited:

$05 / 01 / 2017$

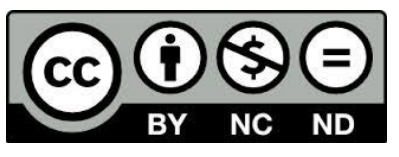

This work is licensed under a

Creative Commons Attribution-NonCommercial-NoDerivatives 4.0 International licence 


\section{Editorial: Thinking and Doing Children's Emotional Geographies}

Matej Blazek (Loughborough University) and Morgan-Windram Geddes (University of Dundee)

The burgeoning fields of children's and emotional geographies share a lot in common. Whilst both emotions and children have a long-standing presence, surges that placed them within the disciplinary mainstream are dated mainly over the last 10 to 20 years. Pivotal papers (James 1990; Philo 1992; Matthews and Limb 1999; Anderson and Smith 2001; Davidson and Milligan 2004; Davidson and Bondi 2004; Thien 2005; Tolia-Kelly 2006), agenda-advancing book-volume publications (Valentine and Skelton 1998; Holloway and Valentine 2000; Aitken 2001; Davidson et al. 2005; Smith et al. 2009; van Blerk and Kesby 2008; Holt 2011), and knowledge exchanges taking place in the newly established specialised journals (Children's Geographies in 2003; Emotion, Space and Society in 2008) and at flourishing international conferences ( 3 editions of International Conferences of Geographies of Children, Young People and Families since 2007 and 4 of International and Interdisciplinary Conferences on Emotional Geographies since 2002) have succeeded in problematizing, shifting and innovating directions in epistemology, methodology, representation and ethics in thematic debates, in the broader field of human geography, but also reaching outside the discipline. However, dialogue between these fields remains limited. Whilst children's emotions certainly have been addressed by geographers (Nayak 2003; Hemming 2007; Horton and Kraftl 2009; den Besten 2010; Pain et al. 2010; Pyer et al. 2010; Brown 2011), we believe that there needs to be greater and more focused mutual engagement on such questions as how emotions matter in the spatialities of children's lives (Horton and Kraftl 2006; Hadfield-Hill and Horton 2013) and what is at stake in researching them (Valentine 1999; Robson 2001; Barker and Smith 2001; Horton 2001; Gaskell 2008). It is also important to question if and how children's geographies can and should speak towards the broader field of emotional geographies and to debates in cognate disciplines and practice. 
In addressing these questions, this special issue brings together some of the most recent work by children's geographers and others. Whilst empirical fieldwork underpins a majority of the papers, they are all focused on conceptual and methodological insights - on thinking and doing children's emotional geographies. The collection has developed from two RGS-IBG Annual Conference sessions in 2011 on “Researching and (Re-)Imagining Children's Emotions in Geography: Conceptualisations and Methodologies", and also includes additional invited contributors.

The papers are diverse in terms of their geographical and disciplinary settings, but within the range of issues covered, eight themes form the common threads.

First, the papers present children's emotions as firmly situated within the wider contexts of children's lives. In so doing they highlight the need to view children's emotional geographies as inseparable from the social, cultural, economic and political landscapes of childhood, whether they are situated in the moral patterns of gender and age (Windram-Geddes), fluid and less fluid spaces of journeying 'near and far' (Murray and Mand), racial and cultural constructions of families and communities (Wood), or the intersectional social and cultural constructions of (dis)ability and age (Holt et al.). The authors show how children's emotions and emotional experiences are intertwined with other facets of their lives, putting emotions and emotional experiences on view as simultaneously constitutive and constituted.

Second, the papers foreground the complexity of the media through which children's emotions emerge, are channelled, and come to matter in everyday actions and interactions. The elusiveness and "difficult-to-approach" character of emotions are illustrated through various papers: WindramGeddes and Bartos highlight interplays between emotions and embodiment, experienced from the "outside" and "inside", through senses and discourses; Kraftl explores 'more-than-social' components of emotions, drawing on theories of attachment and non-human agency, among others; Jones argues for seeing children as nonrepresentational subjects, and the agency through which their emotions are fostered as always emergent, other(ed) and ongoingly (dis)connected; the 


\section{Editorial: Thinking and Doing Children's Emotional Geographies}

richness of intersubjective practices of/with children is at the forefront of Blazek's paper as he advocates approaching children's emotions without requirements to have them voiced. In contrast, Dickens and Lonie emphasise the very power of voice, as they explore in detail the routes through which young people articulate their experiences by writing rap lyrics in the process of youth work.

Third and relatedly, several papers in the special issue critically reflect on the 'otherness' of childhood and on the spatialities of power in child-adult relationships that co-constitute emotional geographies of childhood. Jones gives a post-colonially informed critique of the politics of childhood based on the ordering and purifying of children's environments. Instead, he is proposing spatial and emotional autonomies for the process of 'becoming child', embedded within relationships with adults capable of providing care, love and support. As a research strategy, Blazek highlights our relationships and very being with children as a focal point of research on children and emotions. His paper emphasises intersubjectivity and suggests that at times we might have no chance but to focus on this dynamic in-betweenness, rather than on children's emotions themselves. Refraining from conceptualising children as detached objects is also evident in Procter's account of emotional reflexivity and of the moments, memories and shifts in how researchers make meanings in research with children. Murray and Mand explore children's practices of resistance against the exertions of adult power, incited through the mobility in space. The theme of power and (often subtle) resistance within the context of children's practices in school and family is present also in Windram-Geddes's and Holt et al.'s papers.

Fourth, whilst all authors show remarkable attentiveness to individual stories of their research participants, some also highlight the collective dimension of the formation of feelings. Whether it is through the explorations of the affective spaces of friendship and peer relationships in school and elsewhere (Holt et al.), of physical exercise, food consumption cultures and discourses of the body image (Windram-Geddes) or of young people's community spaces, council estates and youth centres (Wood, Dickens and Lonie), the special issue highlights the supra-individual emotional transitions 
and dynamics developed through children's everyday encounters, ultimately underlining how spaces of emotional relationality matter for individual feelings.

Fifth, the collection illustrates the potential of new kinds of theoretical engagement. Whilst all papers provide solid (and diverse) theoretical underpinning for the case studies and debates they present, three introduce and/or formulate theoretical perspectives that are rather novel to the broader field of geography. Holt et al. introduce the concept of emotional capital, linking the work of Judith Butler and Pierre Bourdieu in their exploration of emotional inter-dependence in children's social relationships; Blazek introduces Anna Freud's perspective on psychoanalysis and particularly the theory of defence mechanisms in order to understand the unspoken dynamics of children's emotions and practices; and Kraftl brings insights from theories of attachments and neuroscience to develop the 'more-than-social' notion of emotions, and hybrid, biosocial concept of childhood.

Sixth, the papers also demonstrate methodological innovations and illustrate their importance in researching children's emotions. Dickens and Lonie, Murray and Mand, Wood, Bartos, Procter and Holt et al. all make central use of visual techniques and audio/video/photo technologies in their effort to give participants resources with which to develop a rich account of their experiences. Papers that are situated in a broader ethnographic framework (Dickens and Lonie, Holt et al., Blazek, Procter and Windram-Geddes) reflect on the positional complexity of the researchers working with children in the settings of school and/or community, and give accounts of innovative and flexible activities that were deemed important to conduct the research, ranging from den building in Procter's paper to counselling provision in Blazek's. The value and importance of narrative techniques is still maintained and emphasised in most empirical papers, albeit with remarks on the importance of reflexivity and elasticity in how interviews, focus groups and other forms of verbal communication with children unfold.

Seventh, various papers in this special issue convey the importance of emotions and emotional geographies in child-related policy and practice. Dickens and Lonie show how emotions are a well- 


\section{Editorial: Thinking and Doing Children's Emotional Geographies}

reflected aspect of the actual pedagogic process within a youth offending programme, in contrast to how this programme and its policies are written. Kraftl questions links with biopolitics and orderings of social space and urges consideration of how the very motivations to engage with children's emotions are translated into the governance of children's lives. Holt et al., Procter, Wood and Windram-Geddes all scrutinise how emotions are overlooked, reflected and/or manipulated in the development of policy and practice in formal educational spaces, in relation to themes such as inclusive education, youth citizenship and physical education respectively.

Finally, a number of the contributors exemplify research which involves extensive work with practitioners and as practitioners (in dual researcher-practitioner roles). While there are distinct divides between political and practitioner agendas on the one hand, and academic research and theory on the other, paying attention to young people's emotions can serve as a key for bridging such divides. Working closely with practitioners, as Dickens and Lonie do, enables a deep understanding of the issues and pressures practitioners face, situated as they are at the intersection between political agendas and participants'/young people's hopes, dreams, and desires.

Researching as practitioners or adopting dual roles, exemplified in different ways by Blazek, Windram-Geddes and Proctor do, raises challenging issues about power, ethics and representation, and about the routes by which it is possible to generate new knowledges about children's lives.

Taken as a group the papers in this special issue problematize some of the ways in which we are doing and thinking children's geographies, and ponder the extent to which emotions play a role in revealing children's lived experiences and knowledges. At the same time, the special issue opens up critical dialogue about the role of children's emotions in emotional geographies,. We also hope that the content of the special issue will invite engagement in theory and practice that reaches beyond the discipline of geography. 


\section{LIST OF REFERENCES}

Aitken, Stuart C., 2001. Geographies of Young People: The Morally Contested Spaces of Identity. Routledge, London.

Anderson, Kay, Smith, Susan, 2001. Editorial: Emotional Geographies. Transactions of the Institute of British Geographers 26 (1), 7-10.

Barker, John, Smith, Fiona, 2001. Power, positionality and practicality: carrying out fieldwork with children. Ethics, Place and Environment 4 (2), 142-147.

Brown, Gavin, 2011. Emotional geographies of young people's aspirations for adult life. Children's Geographies 9 (1), 7-22.

Davidson, Joyce, Bondi, Liz, 2004. Spatialising affect; affecting space: introducing emotional geographies. Gender Place and Culture 11 (3), 373-374.

Davidson, Joyce, Smith, Mick, Bondi, Liz, (Eds.) 2005. Emotional Geographies. Ashgate, London. Davidson, Joyce, Milligan, Christine, 2004. Embodying emotion, sensing space: introducing emotional geographies. Social and Cultural Geography 5 (4), 523-532.

den Besten, Olga, 2010. Local belonging and 'geographies of emotions': immigrant children's experience of their neighbourhoods in Paris and Berlin. Childhood 17 (2), 181-195.

Gaskell, Carolyn, 2008. Isolation and distress"? (Re)thinking the place of emotions in youth research. Children's Geographies 6 (2), 169-181.

Hadfield-Hill, Sophie, Horton, John, 2013. Children's experiences of participating in research: emotional moments together? Children's Geographies. Early view Hemming, Peter, 2007. Renegotiating the primary school: children's emotional geographies of sport, exercise and active play. Children's Geographies 5 (4), 353-371.

Holloway, Sarah L., Valentine, Gill, (Eds.) 2000. Children's Geographies: Playing, Living, Learning. Routledge, London.

Holt, Louise, (Ed.) 2011. Geographies of Children, Youth and Families: International Perspectives. Routledge, London. 
Horton, John, 2001. Do you get some funny looks when you tell people what you do?' Muddling through some angsts and ethics of (being a male) researching with children. Ethics, Place and Environment 4 (2), 159-166.

Horton, John, Kraftl, Peter, 2006. What else? Some more ways of thinking about and doing children's geographies. Children's Geographies 4(1), 69-95.

Horton, John, Kraftl, Peter, 2009. What (else) matters? Policy contexts, emotional geographies. Environment and Planning A 41 (12), 2984-3002.

James, Sarah, 1990. Is there a 'place' for children in Geography? Area 22 (3), 278-283.

Matthews, Hugh, Limb, Melanie, 1999. Defining an agenda for the geography of children. Progress in Human Geography 23(1), 61-90.

Nayak, Anoop, 2003. Through children's eyes: Childhood, place and fear of crime. Geoforum 34 (3), 303-315.

Pain, Rachel, Panelli, Ruth, Kindon, Sarah, Little, Jo. 2010. Moments in everyday/distant geopolitics: Young people's fears and hopes. Geoforum 41 (6), 972-982.

Philo, Chris, 1992. Neglected rural geographies: a review. Journal of Rural Studies 8 (2), 193-207. Pyer, Michelle, Horton, John, Tucker, Faith, Ryan, Sara, Kraftl, Peter, 2010. Children, young people and 'disability': challenging children's geographies? Children's Geographies 8 (1), 1-8.

Robson, Elsbeth, 2001. Interviews worth the tears?: exploring dilemmas in research with young carers in Zimbabwe. Ethics, Place and Environment 4 (2),135-142.

Smith, Mitch, Davidson, Joyce, Bondi, Liz, (Eds) 2009. Emotion, Place and Culture. Asghate, London. Thien, Deborah, 2005. After or beyond feeling? A consideration of affect and emotion in geography. Area 37 (4), 450-454.

Tolia-Kelly, Divya P., 2006. Affect - an ethnocentric encounter? Exploring the 'universalist' imperative of emotional/affectual geographies. Area 38 (2), 213-217.

Valentine, Gill, 1999. Being seen and heard? Ethical dilemmas of research with children and young people. Journal of Ethics, Place and Environment 2 (2), 141-155. 
Editorial: Thinking and Doing Children's Emotional Geographies

Valentine, Gill, Skelton, Tracey, (Eds) 1998. Cool Places: Geographies of Youth Cultures. Routledge, London.

van Blerk, Lorraine, Kesby, Mike, (Eds), 2008. Doing Children's Geographies: Methodological Issues in Research with Young People. Routledge, London. 